\title{
PEMBERDAYAAN MAHASISWA FAKULTAS KESEHATAN MASYARAKAT UNIVERSITAS NUSA CENDANA UNTUK PENGHAPUSAN STIGMA PADA ORANG DENGAN HIV DAN AIDS
}

\author{
Imelda F.E. Manurung ${ }^{{ }^{*}}$ \\ Fakultas Kesehatan Masyarakat, Universitas Nusa Cendana \\ Jl. Adisucipto, Penfui Kupang, Provinsi Nusa Tenggara Timur \\ *Penulis Korespodensi : imelda.manurung@staf.undana.ac.id
}

\begin{abstract}
Abstrak
Stigma pada orang dengan Human Immunodeficiency Virus (HIV) dan Acquired Immuno Deficiency Syndrom (AIDS) adalah salah satu faktor penghambat dalam pengendalian penularan penyakit ini. Mahasiswa adalah kaum intelektual yang diharapkan dapat menjadi agen peubah yang potensial dalam kampus dan masyarakat. Namun masih banyak mahasiswa FKM yang masih memberikan stigma pada penyakit HIV dan AIDS. Oleh karena itu kegiatan ini bertujuan untuk memberdayakan mahasiswa FKM untuk terlibat dalam penghapusan stigma pada orang dengan HIV dan AIDS (ODHA). Metode pelaksanaan yaitu dengan pelatihan, kunjungan ODHA dan praktek dikampus. Hasil dari pengabdian terbentuk 2 kelompok mahasiswa yang memiliki kemampuan untuk melakukan kampanye penghampusan stigma terhadap ODHA. Selain itu mahasiswa juga mampu menyusun materi dan melakukan kampanye pengahapusan stigma pada ODHA di kampus. Dari pengabdian ini dapat disimpulkan bahwa mahasiswa FKM dapat diberdayakan untuk kegiatan kampanye HIV dan AIDS. Mahasiswa adalah individu yang potensial sebagai agen peubah bagi remaja milenial dalam pencegahan HIV dan AIDS.
\end{abstract}

Kata kunci: Pemberdayaan, Stigma, HIV dan AIDS.

\begin{abstract}
Stigma in people with HIV (Human Immunodeficiency Virus) and Acquired Immuno Deficiency Syndrom (AIDS) is one of the inhibiting factors in controlling the transmission of this disease. Students are intellectuals who are expected to be potential agents of change within the campus and society. However, there are still many FKM students who still stigmatize HIV and AIDS. Therefore this activity aims to empower FKM students to be involved in eliminating the stigma on people living with HIV and AIDS (PLWHA). The method of implementation is by training, visiting PLWHA and practicing in the campus. The results of the service were formed by two groups of students who had the ability to campaign for the elimination of stigma against PLWHA. In addition, students are also able to compile material and conduct campaigns to eliminate stigma on PLWHA on campus. From this service it can be concluded that FKM students can be empowered for HIV and AIDS campaign activities. Students are potential individuals as agents of change for millennial teenagers in the prevention of HIV and AIDS.
\end{abstract}

Keywords:Empowerment, Stigma, HIV and AIDS.

\section{PENDAhuluan}

Epidemi HIV dan AIDS adalah masalah global. Laporan WHO 2017 menemukan sekitar 77,3 juta orang sudah terinfeksi HIV dan AIDS. Sekitar 35,4 juta diantaranya telah meninggal dunia. Indonesia adalah salah satu negara di Asia dengan perkembangan kasus paling cepat. Jumlah kasus HIV dan AIDS di Indonesia pada tahun 2018 mencapai 410.788, meningkat dibandingkan tahun 2017 yang mencapai 319.103 kasus. Pada tahun 2018 di Provinsi Nusa Tenggara Timur (NTT) mencapai 6.191 kasus HIV dan AIDS. Pada gambar 1 dapat dilihat sebaran kasus HIV dan AIDS berdasarkan profesi dimana kelompok mahasiswa mencapai 150 kasus. 


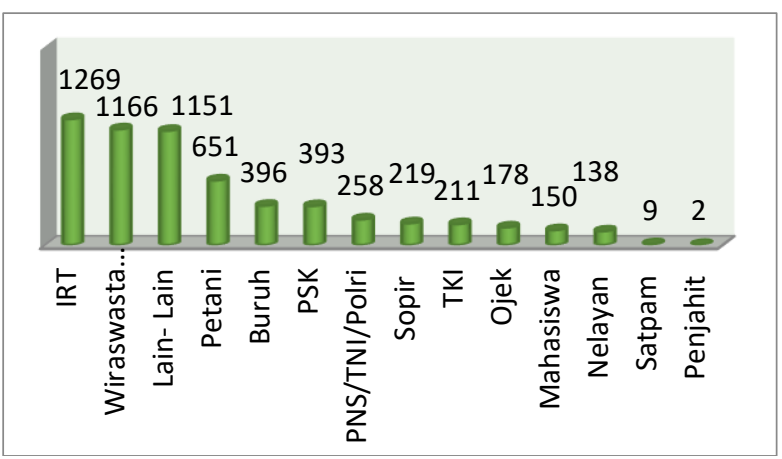

Gambar 1. Distirbusi kasus HIV dan AIDS di Provinsi NTT (sumber: KPA NTT, 2018).

Morbiditas HIV dan AIDS di Provinsi Nusa Tenggara Timur berdasarkan golongan umur tahun 2000 - bulan Desember 2018 ditemukan kelompok umur 20-24 tahun mencapai 733 kasus (KPA NTT, 2018). Pemerintah telah menetapkan program eliminasi HIV dan AIDS melalui misi meniadakan infeksi baru, stigma dan kematian karena AIDS. Program ini dikenal dengan nama' 3 Zeros'. Sasaran dalam melakukan misi adalah dengan melibatkan seluruh lapisan masyarakat (KPAN, 2015).

Faktor penghambat eliminasi HIV dan AIDS adalah rendahnya pengetahuan terkait penularan, pencegahan dan pengobatan. Selain itu adalah masih tingginya stigma dan diskriminasi terhadap orang dengan HIV \& AIDS (ODHA). Stigma berasal dari perilaku yang tidak dapat diterima oleh masyarakat. Stigma terhadap ODHA tergambar dalam sikap sinis, perasaan ketakutan yang berlebihan, dan pengalaman negatif terhadap ODHA (Saki et al., 2015). Banyak yang beranggapan bahwa ODHA adalah orang yang bertanggung jawab terhadap penularan HIV \& AIDS (El-Gadi, Abudher, Sammud, 2018).

Berdasarkan fenomena di atas dapat dilihat bahwa kelompok usia 25-49 tahun adalah kelompok usia paling tinggi kasus HIV dan AIDS. Jika dilihat riwayat alamiah penyakit HIV dan AIDS, maka masa usia pada kelompok mahasiswa adalah masa kritis terjadinya penularan HIV dan AIDS. Untuk itu penting memberdayakan mahasiswa agar dapat menjadi 'agent of change' bagi teman-temannya, lingkungan keluarga dan masyarakat dalam menghapus stigma dan diskriminasi juga melindungi diri dari penularan HIV dan AIDS . Mahasiswa menjadi potensial terhadap kampanye penghapusan stigma pada ODHA karena menjadi kelompok intelektual yang mampu menjelaskan fakta tentang HIV dan AIDS. Kemauan untuk belajar dan berinteraksi sosial dalam mencari identitas diri menjadi komponen penting dalam proses pemberdayaan kelompok ini. Pendekatan teman sebaya yaitu sesama kelompok mahasiswa diharapkan dapat mempengaruhi penghapusan stigma pada ODHA. Tujuan pengabdian ini adalah Pemberdayaan Mahasiswa FKM Universitas Nusa Cendana untuk penghapusan stigma pada ODHA.

\section{BAHAN DAN METODE}

Pelaksanaan pengabdian dilakukan pada 1 Oktober - 9 November 2018. Kegiatan di awali dengan membuat pengumuman kepada seluruh mahasiswa semester VI yang mau sukarela terlibat dalam kegiatan ini. Diperoleh 15 mahasiswa yang akan terlibat untuk kegiatan pengabdian ini. Mahasiswa semester VI tersebut ada yang berasal dari peminatan Gizi, Epidemiologi dan Biosatistika, Kesehatan lingkungan dan kerja, Pendidikan Kesehatan dan Ilmu Perilaku dan Administrasi Kebijakan Kesehatan. Selanjutnya bersama dengan 15 mahasiswa terpilih dilakukan:

\section{a. Identifikasi Masalah}

Dari hasil wawancara terhadap 15 mahasiswa semester VI, masih banyak yang memberikan stigma pada ODHA. Mereka mengaku takut duduk dekat ODHA, HIV dan AIDS adalah penyakit hukuman, demikian juga pengetahuan tentang penularan HIV masih kurang.

b. Alternatif Pemecahan Masalah

Berdasarkan diskusi bersama mahasiswa melalui metode Brainstorming, maka kelompok bersepakat untuk menawarkan alternatif pemecahan masalah dalam mengatasi stigma dan diskriminasi terhadap ODHA melalui penyuluhan tentang stigma dan diskriminasi terhadap ODHA pada mahasiswa.

Kegiatan ini bertujuan untuk mengubah persepsi mahasiswa terhadap ODHA. Mahasiswa menjadi sasaran kegiatan ini karena mahasiswa merupakan generasi milenial yang mampu mejadi agen perubahan dalam mengatasi masalah-masalah sosial yang ada.

c. Kegiatan yang dilakukan

1. Kegiatan sosialisasi pada 15 orang mahasiswa semester VI yang berasal dari peminatan Gizi, Epidemiologi dan Biosatistika, Kesehatan lingkungan dan kerja, Pendidikan Kesehatan dan Ilmu Perilaku dan Administrasi Kebijakan Kesehatan. Kegiatan berlangsung pada 2 Oktober 2018.

2. Mengunjungi rumah singgah ODHA pada tanggal 4 Oktober 2018. Dari kegiatan ini, mahasiswa diminta untuk membuat untuk menuliskan laporannya.

3. Kegiatan Pertemuan ODHA dan OHIDA sedaratan Timor yang berlangsung di Soe pada tanggal 12 Oktober 2018. Mahasiswa di ajak untuk bertemu langsung dengan para ODHA dan OHIDA, sharing bagaimana pergumulan hidup.

4. Mengajak 15 mahasiswa untuk membuat suatu program kegiatan yang ditujukan kepada temantemannya di kampus FKM.

\section{HASIL DAN PEMBAHASAN}

\section{1) Pelatihan HIV dan AIDS Bagi Mahasiswa}

Kegiatan ini ditujukan untuk memperbaiki pengetahuan mitra/mahasiswa, keterampilan sebagai penyuluh dan komitmen mitra untuk terlibat dalam kegiatan menghapus stigma pada ODHA di kampus dan 
masyarakat. Kegiatan ini di fasilitasi KPA Provinsi Nusa Tenggara Timur. Pelatihan dilakukan selama lima hari dengan total kegiatan 10 jam. Setelah pelatihan seluruh pengetahuan dan keterampilan mitra semakin baik sebagai penyuluh HIV dan AIDS. Selain itu, mahasiswa juga bersedia untuk menjadi sukarelawan dalam kegiatan ini. Pada tabel 1 dapat dilihat nilai ratarata sebelum dan sesudah pelatihan pada pengetahuan dan keterampilan meningkat. Demikian juga dengan stigma sebelum pelatihan ]stigma yang diberikan sangat tinggi yaitu mencapai 85, namun setelah diberikan pelatihan tidak ada lagi mahasiswa yang memberikan stigma pada ODHA.

Tabel 1. Nilai rata-rata Pengetahuan, Keterampilan dan Stigma sebelum dan sesudah Pelatihan.

\begin{tabular}{lll}
\hline \multicolumn{1}{c}{ Variabel } & \multicolumn{2}{c}{ Nilai Rata-Rata } \\
\cline { 2 - 3 } & \multicolumn{1}{c}{ Sebelum } & \multicolumn{1}{c}{ Sesudah } \\
\hline Pengetahuan & 40,8 & 96,5 \\
Keterampilan & 35,6 & 90,4 \\
Stigma & 85 & 0 \\
\hline
\end{tabular}

Kelompok mitra yakni mahasiswa memberikan stigma pada ODHA karena kurangnya pengetahuan tentang HIV dan AIDS. Hal ini sejalan dengan hasil kegiatan dimana pengetahuan tentang HIV dan AIDS semakin baik maka tidak ada lagi stigma terhadap ODHA. Stigma pada ODHA terjadi karena rendahnya pengetahuan tentang HIV dan AIDS.

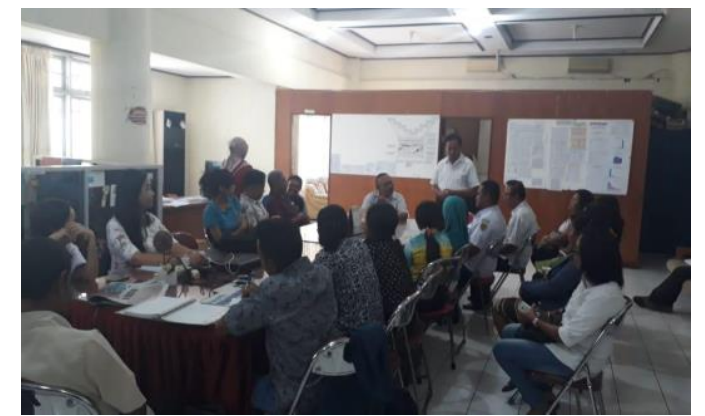

Gambar 1. Pelatihan HIV dan AIDS Bagi Mahasiswa.

Keterampilan kelompok mitra dalam menyampaikan pesan penghapusan stigma terhadap ODHA dapat dilihat dari kegiatan-kegiatan yang mampu dilakukan oleh mitra yaitu memberikan penguatan pada ODHA melalui kegiatan kunjungan rumah singgah ODHA, pertemuan ODHA, Kampanye pada mahasiswa dan advokasi pada Wakil Gubernur NTT terkait penghapusan stigma pada ODHA. Seluruh mitra/mahasiswa yang mengikuti pelatihan memiliki komitmen untuk bersedia diberdayakan dalam kegiatan penghapusan stigma pada ODHA. Hal ini dapat dilihat dari kegiatan yang direncanakan dan dilakukan oleh mitra sebagai berikut.

\section{2) Kegiatan Mengunjungi Rumah Singgah ODHA} Kegiatan ini bertujuan untuk mengenal dan menjalin interaksi dengan ODHA yang berada di rumah singgah serta melihat secara dekat kondisi ODH A. Dari perkunjungan ini mahasiswa dapat berinteraksi langusung dengan ODHA. Kegiatan kunjungan ini bertujuan untuk menjalin keakraban serta untuk mengetahui informasi singkat tentang kehidupan ODHA secara rutin, mulai dari melakukan pemeriksaan diri ke RSU W.Z Yohanes dan pengambilan obat ARV (anti retroviral) untuk dikonsumsi. ODHA yang berada di rumah singgah berjumlah dua orang berasal dari Kabupaten Rote Ndao, dan satu penderita TBC yang berasal dari Sabu raijua.

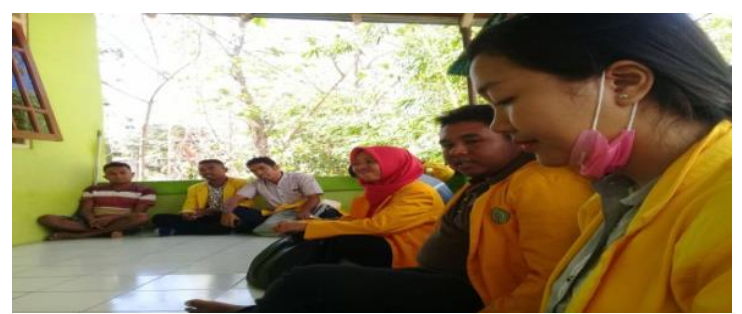

Gambar 2. Kunjungan ke Rumah ODHA.

3) Pertemuan Dengan ODHA dan OHIDHA seDaratan Timor Yang Dilaksanakan di Soe

Pertemuan ODHA sedaratan Pulau Timor ini merupakan kegiatan kemitraan yang dilakukan LSM Perjuangan dengan mitra KPA dan donatur lainnya. Kegiatan ini bertujuan untuk mengumpulkan semua ODHA dan OHIDHA serta dinas terkait yaitu Dinas Sosial dan Dinas Kesehatan agar mendukung para ODHA dan OHIDHA dalam menjalani kehidupan secara mandiri. Pada kesempatan ini mitra/mahasiswa memberikan motivasi kepada ODHA untuk meningkatkan kualitas hidupnya.

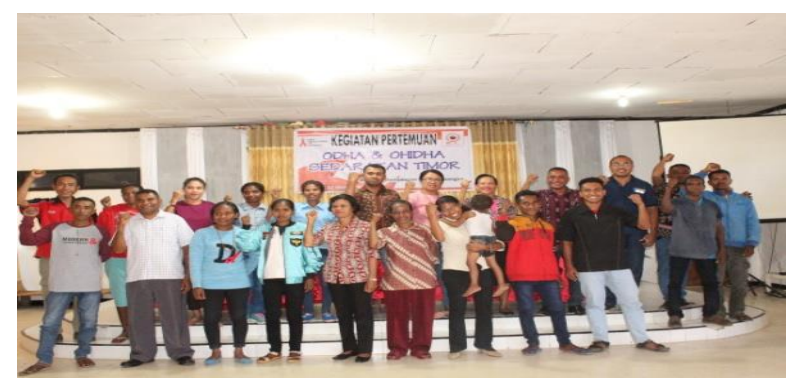

Gambar 3. Pertemuan ODHA dan OHIDHA.

4) Kampanye penghapusan stigma terhadap ODHA Dalam kegiatan ini mitra sepakat untuk melakukan suatu kegiatan yaitu kampanye penghapusan stigma bagi ODHA. Mahasiswa menyusun acara kegiatan yang dilaksanakan pada tanggal 3 November 2019. Sekitar 500 mahasiswa hadir dalam kegiatan kampanye penghapusan stigma pada ODHA. Seluruh mahasiswa yang hadir begitu semangat mengikuti acara. Kegiatan yang dilakuan dalam bentuk orasi, penyuluhan dan renungan. Hasil kegiatan ini yaitu diperoleh komitmen bersama untuk mengkampanyekan 'Stop Stigma Pada ODHA'. Kegiatan advokasi dilakukan kepada staf kantor gubernur yang diterima oleh Bapak Wakil Gubernur. Hasil kegiatan ini diperoleh komitmen pemerintah provinsi untuk memperhatikan kehidupan ODHA yaitu menjamin hak-hak ODHA. 


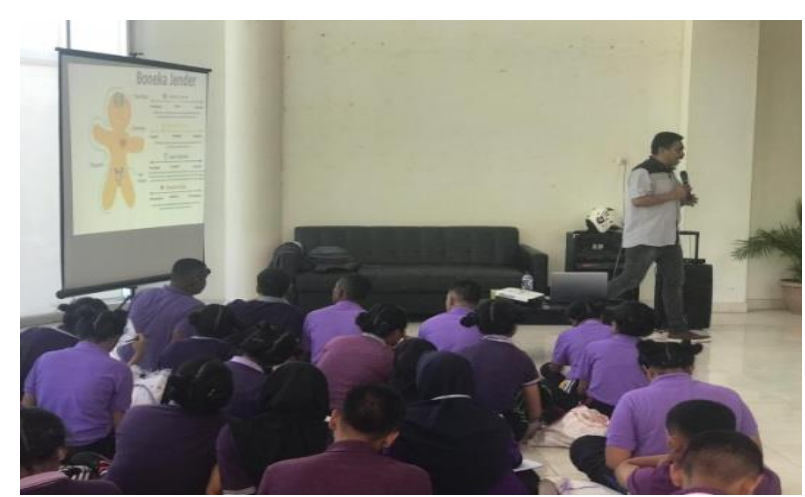

Gambar 4. Kampanye Penghapusan Stigma Terhadap ODHA.

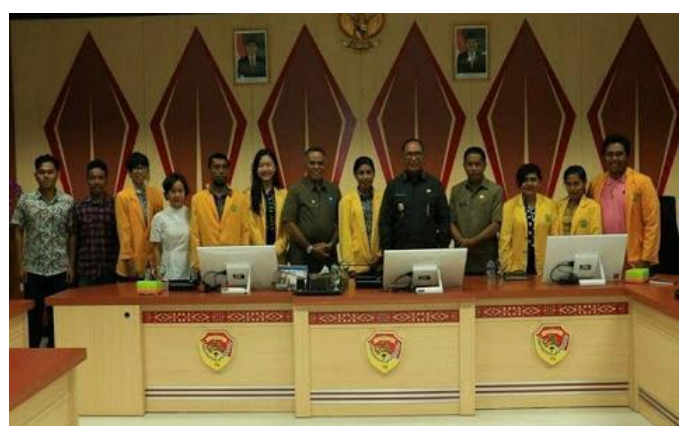

Gambar 5. Advokasi kepada Wakil Gubernur NTT.

\section{KESIMPULAN DAN SARAN}

1. Pelatihan memperbaiki Pengetahuan dan keterampilan mitra tentang kampanye penghapusan stigma pada ODHA.

2. Semua mitra tidak memberikan stigma pada ODHA setelah mengikuti pelatihan kampanye HIV dan AIDS

3. Semua mitra bersedia diberdayakan untuk melakukan kampanye penghapusan stigma pada ODHA yang ditujukan pada mahasiswa dan pemerintah.

Mahasiswa adalah mitra yang potensial untuk diberdayakan dalam kampanye penghapusan stigma. Pelatihan dan pendampingan terkait issu HIV dan AIDS pada mahasiswa akan memperkuat komitmen mereka untuk bersedia diberdayakan. Oleh karena itu pemerintah diharapkan dapat melibatkan mahasiswa dalam program HIV dan AIDS.

\section{DAFTAR PUSTAKA}

El-Gadi, S., Abudher, A., Sammud, M. (2018). HIVrelated knowledge and stigma among high school students in Libya. International Journal of STD and AIDS. 19(3), 178-183.

KPAN (2015). Strategi dan Rencana Aksi Nasinal 2015-2019, Penanggulangan HIV dan AIDS di Indonesia.

KPA NTT (2018). Laporan Tahunan Komisi Penanggulangan HIV dan AIDS Provinsi Nusa Tenggara Timur.

Saki, M., Kermanshahi, S., Mohammadi E., Mohraz, M. (2015). Perception of patients with
HIV/AIDS from stigma and discrimination. Iran red Crescent Medical Journal, 17(6). WHO (2017). Fact Sheet HIV and AIDS. 